International Journal of

Advanced Science and Convergence

\title{
A Study on the Financial Management Model of Business Group in the Era of Big Data
}

\section{Xiaoqin Wang}

Ph.d student, Department of Global Business, Gachon University, Seongnam, 13120, Korea

\begin{abstract}
Background/Objectives: In the Internet age of information technology development, the development of big data promotes the deepening of economic globalization and the competing market, and the enterprise management changes. More and more business groups are starting to study effective financial management models. The purpose of this paper is to find effective financial management models suitable for business groups in the context of new trends in the economic environment. Methods/Statistical analysis: For this purpose, this paper takes the representative Huayao Company in China as a case to study. Findings: The results show that the financial centralized management model can adapt to the trend of the enterprise and reduce the risk of the enterprise. Improvements/Applications: This study provides a theoretical basis for the generalization of enterprise groups with centralized financial management.
\end{abstract}

\section{Index Terms}

big data, business groups, financial centralized management, Internet, risk control

\footnotetext{
Corresponding author: Xiaoqin Wang

710548657@qq.com

- Manuscript received September 29, 2021.

- Revised November 3, 2021; Accepted December 20, 2021

- Date of publication December 31, 2021.

(c) The Academic Society of Convergence Science Inc.

2619-8150 @ 2019 IJASC. Personal use is permitted, but republication/redistribution requires IJASC permission.
} 


\section{INTRODUCTION}

This Companies that adopt a group model are typically parent-child enterprises. Such enterprises generally have several subsidiaries at the core of the parent company and have a more diversified management model than ordinary single-tier enterprises [1]. Such a business model faces a series of problems such as information barriers and delays in business decision making. As a result, large business groups began to look for a management system suitable for parent-child enterprises, in particular, exploring the financial management system [2]. Among them, the centralized financial management model is highly regarded for strengthening capital control and improving management efficiency. Therefore, it has become a new trend in financial management for national and international enterprise groups [3].

More than $80 \%$ of the world's top 500 companies have adopted a financial centralized management model, and large Chinese companies are adopting it one after another [4]. For example, Sinopec and China Mobile are implementing financial intensive management before and after strengthening financial risk control to enhance their management.

In financial risk control, each branch and business unit are more eager to pursue performance and receive high rewards, and reckless pursuit of performance affects the effectiveness of internal control [5].

The purpose of this paper is to find effective financial management models suitable for business groups in the context of new trends in the economic environment. Therefore, this paper discusses the necessity and risk control mode of Huayao company's financial centralization management model, which is suitable for the business group.

In the era of market economy development and economic globalization, enterprise groups have become a common form of organization adopted by modern enterprises. The larger the size of the enterprise, the higher the requirement for financial control. Facing a complex and varied enterprise environment, we can increase the financial control of the enterprise and make comprehensive use of internal and external resources to ensure that the company's overall strengths are fully realized. At the same time, China's economy is constantly developing and opening up to the outside world. Today, the main trend of enterprise development has become internationalization and marketization.

In China, amid the reform of state-owned enterprises and the rise of mixed-ownership enterprises, corporate management has not been synchronized with economic development, particularly in financial management. This negatively affects corporate governance and ultimately affects corporate growth. From this, it can be seen that the research on the financial management model of enterprise is of great significance to the corporate governance and development.

\section{TheORETICAL BACKGROUND AND RELATED STUDIES}

Centralization and decentralization are two models in corporate financial management. The financial management system of enterprises is the system of determining the financial responsibilities, rights and interests of enterprises at all levels. The main content is how financial management authority is distributed. The financial management operating system and implementation method of the enterprise are determined by the financial management system of the enterprise [6].

The centralized financial management system refers to the centralized management of the financial management rights of the subordinate units, which have no financial decision-making power. The finance department of the corporate headquarters participates in both the decision-making process and the decision-making process. Under this centralized mechanism, the entire enterprise's management authority is concentrated in the enterprise's higher organization, and each subordinate unit can only follow the instructions of the higher organization.

Decentralized financial management system refers to the distribution of financial decision-making rights and management rights to subordinate organizations, each of which has to report the results of execution and record the results. The management authority of the enterprise is distributed to the subordinate units. Although each subordinate unit has the right to make decisions, each subordinate unit only considers its own interests and conducts financial activities from its own perspective. Finally, it leads to unequal distribution of resources, increased cost of capital distribution, and unbalanced distribution of profits.

Corporate governance is to optimize the relationship between stakeholders at the company level, promote the interests of all stakeholders in the enterprise, and promote the smooth production and operation of the enterprise. On the one hand, corporate governance can provide the theoretical foundation for centralized financial management, the basis for the implementation of rules and systems and the arrangement of organizational structure. On the other hand, there is a certain difference between the two. Corporate governance mainly solves the distribution of control of the company, and centralized financial management solves the distribution of control of finance.

Financial centralized management enables 
centralized control by integrating resources within finance by establishing efficient information delivery and sharing mechanisms through a complete information network [7]. Under the mode of centralized financial management, the internal funds are arranged in a unified manner, ensuring the timely flow of funds and the value-added preservation, reducing financial risk and reducing the cost of funds. In addition, the financial data of each branch is managed through integrated accounting, eliminating asymmetry in information between each branch.

Currently, there are three main types of financial intensive management: One is the centralized management model of the headquarters. Under this model, the headquarters is responsible for the revenue and expenditure of all affiliates within the group. Cost approval, budget management, and funding approval authority are concentrated in the headquarters, which can reduce operating costs, improve financial performance, and maximize the value of the value of the enterprise. The second is the zone management model. A secondary finance department is established and financial data is entered into the group system and sent directly to the headquarters finance office. Headquarters finance establishes different positions for review and bookkeeping by dedicated personnel. The third is a three-level management model. The Headquarters has a tier one management center responsible for group investment, financing, settlement and supervision. Each province and city have a secondary management center, which is responsible for budget approval, financial management and cost control in the region. Affiliates in each region are solely responsible for the entry of financial and business data.

DeChow and Mooreitsen (2005) believes that internal financial firms, such as financial firms and internal banks, will be able to raise enough internal funds. Such organizations make money easier to operate, cheaper, and more targeted and flexible [8].

Kroll (2006) proposed two basic principles in the group's fund management process, namely, "sharing," which aims to share and allocate funds at different levels. Another principle is "benefit", which optimizes the allocation of funds, increases the yield on capital and efficiency of utilization, and stimulates the initiative of all member units to participate in the centralized management of funds [9].

Walter and Kenesei (2015) believe that internal financial organizations, including internal banks, clearing houses, or financial firms, play a crucial role in centralizing the management of funds. The financial and financial services they provide for the exhibition are now necessary for the development of enterprise groups, which are in line with the trend of economic development, but should be carefully supervised at the same time [10].

Jeffrey (2016) examined the centralized management of funds in terms of risk prevention. He believes that the continuous development of the enterprise has led to the management of funds becoming an important part of the operation of the enterprise. However, there are differences in development stages and management directions of the same industry based on the different business conditions. Therefore, the management pattern of funds between companies differs from person to person [11].

Kasiran, Mohamad and Chin (2016) have raised some issues with the group's centralized management of funds. First of all, we need to strengthen our understanding of the management of 5 funds and increase the concentration of funds. In addition, at the operational level, control of the flow and flow of funds can be made more timely and accurate [12].

\section{HuAYAO COMPANY'S FINANCIAL MANAGEMENT MODEL}

Huayao was established in 2000. After 20 years of development, the registered capital is 2001 million RMB in 2020, and the annual income has reached hundreds of million RMB.

The finance of the head office and its subsidiaries has always been independently calculated and kept separate financial accounts. In the process of development, the company incorporated the financial management of its affiliates several times, but gave up financial management for various reasons, and in 2018, it was able to manage its finances again using Zhongda's financial software.

Table 1 shows the assets and profits of Hwayo Group (including subsidiaries) from 2012 to 2020, and Table 2 shows the assets and profits of Huayao Company (without subsidiaries) from 2012 to 2020.

Table 1: HuAYAo GROUP'S ASSET AND INCOME

(unit:RMB)

\begin{tabular}{|c|c|r|c|}
\hline Year & Asset & $\begin{array}{c}\text { Main business } \\
\text { income }\end{array}$ & Net income \\
\hline 2012 & $30,760,530.78$ & $32,547,239.43$ & $1,382,128.19$ \\
\hline 2013 & $35,291,261.81$ & $43,003,719.92$ & $1,165,255.83$ \\
\hline 2014 & $43,224,140.90$ & $58,084,617.53$ & $1,785,387.31$ \\
\hline 2015 & $49,568,915.75$ & $71,639,378.68$ & $3,642,554.55$ \\
\hline 2016 & $56,635,414.32$ & $77,013,706.91$ & $1,968,832.30$ \\
\hline 2017 & $68,000,791.98$ & $86,811,211.46$ & $2,262,081.90$ \\
\hline 2018 & $88,732,095.03$ & $123,426,769.15$ & $6,167,013.25$ \\
\hline 2019 & $84,288,317.73$ & $124,362,070.32$ & $1,063,732.48$ \\
\hline
\end{tabular}




\begin{tabular}{|l|l|l|l|}
\hline 2020 & $80,066,848.54$ & $137,951,422.76$ & $-492,223.26$ \\
\hline
\end{tabular}

Source: Author's Calculation Using Huayao group (including subsidiaries) from 2012 to 2020 [13-21]

Table 2. Huayao COMPANY'S ASSET AND INCOME

(unit:RMB)

\begin{tabular}{|c|c|c|c|}
\hline Year & Asset & $\begin{array}{c}\text { Main business } \\
\text { income }\end{array}$ & Net income \\
\hline 2012 & $18,262,565.28$ & $7,330,583.85$ & $182,200.48$ \\
\hline 2013 & $19,459,540.05$ & $12,230,077.87$ & $443,566.84$ \\
\hline 2014 & $22,202,855.77$ & $18,327,284.52$ & $475,996.06$ \\
\hline 2015 & $24,806,941.45$ & $23,912,833.62$ & $503,758.15$ \\
\hline 2016 & $29,385,780.46$ & $28,241,685.70$ & $349,345.56$ \\
\hline 2017 & $32,390,360.70$ & $32,921,215.49$ & $358,129.55$ \\
\hline 2018 & $34,007,518.88$ & $54,156,889.91$ & $535,518.13$ \\
\hline 2019 & $31,857,510.90$ & $43,182,026.42$ & $84,056.82$ \\
\hline 2020 & $28,591,732.84$ & $45,913,580.22$ & $130,371.85$ \\
\hline
\end{tabular}

Source: Author's Calculation Using Huayao company (without subsidiaries) from 2012 to 2020 [13-21].

Table 3 shows the liquid asset of Hwayo Group (including subsidiaries) from 2012 to 2020 , and Table 4 shows the liquid asset of Huayao Company (without subsidiaries) from 2012 to 2020.

Table 3. Huayao group's LIQUid ASSET

\begin{tabular}{|c|c|c|c|}
\hline Year & monetary funds & $\begin{array}{c}\text { accounts } \\
\text { receivable }\end{array}$ & liquid asset \\
\hline $\begin{array}{c}201 \\
2\end{array}$ & $6,638,248.33$ & $5,524,975.74$ & $25,822,169.83$ \\
\hline $\begin{array}{c}201 \\
3\end{array}$ & $8,122,446.07$ & $8,958,838.34$ & $30,941,522.19$ \\
\hline $\begin{array}{c}201 \\
4\end{array}$ & 12379325.82 & 10474612.67 & 39507028.9 \\
\hline $\begin{array}{c}201 \\
5\end{array}$ & $14,497,302$ & $12,139,688.54$ & $46,274,612.57$ \\
\hline $\begin{array}{c}201 \\
6\end{array}$ & $15,842,763.69$ & $15,930,966.34$ & $54,050,140.66$ \\
\hline $\begin{array}{c}201 \\
7\end{array}$ & $18,698,163.44$ & $16,242,784.10$ & $63,851,662.85$ \\
\hline $\begin{array}{c}201 \\
8\end{array}$ & $27,370,698.62$ & $29,413,123.82$ & $83,481,527.48$ \\
\hline $\begin{array}{c}201 \\
9\end{array}$ & $26,546,885.37$ & $30,551,860.11$ & $79,766,942.35$ \\
\hline $\begin{array}{c}202 \\
0\end{array}$ & $27,136,960.50$ & $26,844,206.85$ & $75,680,878.75$ \\
\hline
\end{tabular}

Source: Author's Calculation Using Huayao group (including subsidiaries) from 2012 to 2020 [13-21] .

Table 4. HUAYAO COMPANY'S LIQUID ASSET

\begin{tabular}{|c|c|c|c|}
\hline Year & $\begin{array}{c}\text { monetary } \\
\text { funds }\end{array}$ & $\begin{array}{c}\text { accounts } \\
\text { receivable }\end{array}$ & liquid asset \\
\hline
\end{tabular}

\begin{tabular}{|c|c|c|c|}
\hline 2012 & $3,501,031.86$ & $2,100,062.29$ & $14,442,302.27$ \\
\hline 2013 & $651,570.76$ & $4,312,395.40$ & $15,966,324.47$ \\
\hline 2014 & $2,926,095.35$ & $4,417,568.65$ & $19,436,469.33$ \\
\hline 2015 & $3,083,841.92$ & $5,378,290.95$ & $22,863,803.02$ \\
\hline 2016 & $4,886,506.99$ & $7,709,006.92$ & $28,199,520.30$ \\
\hline 2017 & $7,304,371.24$ & $8,577,826.76$ & $31,046,084.00$ \\
\hline 2018 & $5,779,954.90$ & $15,194,710.53$ & $33,209,409.00$ \\
\hline 2019 & $10,027,427.66$ & $14,983,203.60$ & $31,026,408.02$ \\
\hline 2020 & $3,395,586.20$ & $15,981,950.42$ & $25,493,566.09$ \\
\hline
\end{tabular}

Source: Author's Calculation Using Huayao company (without subsidiaries) from 2012 to 2020 [13-21] .

The account payable and tax payable of a company can be studied for changes in its profitability. Table 5 shows the liabilities of Hwayo Group (including subsidiaries) from 2012 to 2020, and Table 6 shows the liabilities of Huayao Company (without subsidiaries) from 2012 to 2020 .

Table 5. HuAYAO GROUP'S LIABILITIES

(unit:RMB)

\begin{tabular}{|c|c|c|c|}
\hline Year & $\begin{array}{c}\text { Accounts } \\
\text { Payable }\end{array}$ & Tax Payable & $\begin{array}{c}\text { Current } \\
\text { liabilities }\end{array}$ \\
\hline 2012 & 279467.52 & 305255.37 & 14106716.51 \\
\hline 2013 & 281002.52 & 937637.07 & 17792402.72 \\
\hline 2014 & 359478.59 & 1003026.22 & 24231939.33 \\
\hline 2015 & 733,046 & & $29,860,921.72$ \\
\hline 2016 & 32,676 & $1,054,404.94$ & $34,469,326.32$ \\
\hline 2017 & $106,912.80$ & $1,139,625.26$ & $46,294,489.25$ \\
\hline 2018 & $1,837,221.72$ & $1,628,126.74$ & $61,483,898.93$ \\
\hline 2019 & $10,233,378.87$ & $1,536,823.46$ & $57,600,536.43$ \\
\hline 2020 & $9,322,766.04$ & $1,611,446.20$ & $53,415,812.79$ \\
\hline
\end{tabular}

Source: Author's Calculation Using Huayao group (including subsidiaries) from 2012 to 2020 [13-21] .

Table 6: HuAYAO COMPANY's LIABILITIES

\begin{tabular}{|c|c|c|c|}
\hline Year & $\begin{array}{l}\text { Accounts } \\
\text { Payable }\end{array}$ & Tax Payable & $\begin{array}{c}\text { Current } \\
\text { liabilities }\end{array}$ \\
\hline 2012 & 900 & $54,045.80$ & $6,742,019.14$ \\
\hline 2013 & 900 & $557,235.37$ & $7,556,784.38$ \\
\hline 2014 & 11,600 & $347,797.65$ & $9,739,425.70$ \\
\hline 2015 & 11,600 & $396,291.07$ & $11,842,266.76$ \\
\hline 2016 & 11,600 & $386,251.60$ & $16,080,169.54$ \\
\hline 2017 & 11,600 & $340,348.05$ & $18,728,807.65$ \\
\hline 2018 & 11,600 & $453,652.73$ & $20,211,517.46$ \\
\hline 2019 & $3,750,198.60$ & $391,437.63$ & $18,108,670.82$ \\
\hline 2020 & $3,701,904.15$ & $663,906.42$ & $15,515,548.56$ \\
\hline
\end{tabular}


company (without subsidiaries) from 2012 to 2020 [13-21].

\section{A. The Necessity of Centralized Finance Management at Huayao Company}

First, as the company grows, the number of branch offices and layers of the company increases, and the gap between corporate governance and culture increases. The centralized financial management can not only achieve the unity of financial settlement methods, but also promote the management system of the head office.

Second, the lack of timely or inconsistent response to the head office's financial system can affect the company's management plans and strategy implementation. Centralized financial management helps to better execute the head office's strategic plans, allowing each branch to operate independently while keeping pace with the head office's strategic vision and reducing the head office's operating costs.

Third, financial centralized management allows the company's decision-makers to have all the data in hand, and financial data is the embodiment of other business activities. The head office can interpret the actual operations of each branch from financial data and manage each branch more efficiently.

\section{B. Huayao's Risk of Financial Centralized Management}

First of all, centralized financial management will increase the approval process between the head office and each branch office. There is a risk of inefficiency in managing funds within the company due to the time it takes to deliver data between headquarters and branch offices. The second risk is accounting quality risk. The head office will not know the truth about each branch in time, and some of them will not. This creates a quality risk in terms of legitimacy, compliance and rationality of accounting data. Zhongda's financial software itself also poses risks. Defects in accounting procedures and software upgrades make accounting, accounting and examination complicated, making financial transactions less efficient and more risky.

\section{HuAyaO's Risk CONTROL APPROACH TO FinANCIAL CENTROLIZED MANAGEMENT}

First, the company established a unified control platform. Huayao company has grown to the present day, with more than 60 branches and the management process is complicated and varied. Huayao uses the power of information management system technology to combine these tasks organically.

Next, the company integrated management accounting subjects. Since 2018, Huayao's headquarters has asked all of its affiliates to use Zhongda's financial software to set up integrated accounting subjects.

In addition, the company establishes accounting policies and records management in a unified manner

The head office of Huayao has certain privileges in setting parameters. The higher level can protect certain important parameters and the lower level can only use them that cannot be modified.

\section{CONCLUSIONS AND IMPLICATIONS}

Huayao Company's financial centralized management is based on network development technology to unify the financial system and financial accounting work, effectively guarantee the quality of accounting information and perfect the financial supervision function. At the same time, the company has improved its ability to prevent risks and control risks in financial management. Companies can also revolutionize new models of financial management by combining the advantages of a financially intensive management model.

In this case study, we realize that the financially intensive management model can adapt to the trends of the enterprise and reduce the risk of the enterprise and achieve efficient management. This study provides a theoretical basis for the generalization of business groups with centralized financial management.

The shortcoming of this paper is that a case study of a company may not be applicable to other industries or other countries. It is better to select representative companies from various countries and industries in future studies.

\section{REFERENCES}

[1] Liu, C. (2009). Enterprise Group's financial management control behavior: Kinematics, speed measurement and phase correlation. Northern Beijing: Economic Science and Technology. 78-80 (In Chinese).

[2] Zhou, X. \& Liu, X. (2011). Questions and suggestions for improvement in the development process of Corporate Finance Corporation. Finance and Society: Research and Exploration, (10), 35-37 (In Chinese)..

[3] Chen, Y. (2018). Research on the central configuration of enterprise finance sharing service in the age of big data. Chinese Management and Interest, 21(24), 70-71 (In Chinese)..

[4] Wang, J. (2021). The background of big data is to promote the financial management of enterprise groups. Accounting for township enterprises in China. (9), 170-171 (In Chinese).

[5] Yin, H. (2021). Investigating the Effective Management of Funds and Financial Risk Control in Mining Enterprises. Chinese Market, (25),170-171(In Chinese). 10.13939/j.cnki.zgsc.2021.25.170. 
[6] Fu, Y. (2019). The background of big data: Focused financial management for enterprise groups. Accounting Studies, (18), 17-18 (In Chinese).

[7] Petrisor, I. \& Cozmiuc, D. (2016). Specific business models for romanian companies: finance shared services. ProcediaSocial and Behavioral Sciences, 159-164. DOI : 10.1016/j.sbspro.2016.05.102.

[8] Dechow, N. \& Mouritsen, J. (2005). Enterprise resource planning systems, management control and the quest for integration. Accounting, Organizations and Society, 30(7), 691-733.

DOI : $10.1016 / j$.aos.2004.11.004.

[9] Kroll, K. M. (2006). Best practices in cash management: Information and automation are key. Business finance, 12(2), $17-20$.

[10] Walter G, Kenesei B. (2015). Innovative Banking Services for Centralised Corporate Cash Management. Public Finance Quarterly, 60(3): 312-325.

[11] Jeffery, S. (2016). Centralize treasury management to reduce risk, increase control. Financial Executive. 2016(3), 34-46.

[12] Kasiran, F. W., Mohamad, N. A. \& Chin, O. (2016). Working capital management efficiency: A study on the small medium enterprise in malaysia. Procedia Economics and Finance, 2016(41), 156-168 DOI : 10.1016/S2212-5671(16)00037-X.

[13] Huayao group, (2012), Annual Reports, Hangzhou, China: author.

[14] Huayao group, (2013), Annual Reports, Hangzhou, China: author.

[15] Huayao group, (2014), Annual Reports, Hangzhou, China: author.

[16] Huayao group, (2015), Annual Reports, Hangzhou, China: author.

[17] Huayao group, (2016), Annual Reports, Hangzhou, China: author.

[18] Huayao group, (2017), Annual Reports, Hangzhou, China: author.

[19] Huayao group, (2018), Annual Reports, Hangzhou, China: author.

[20] Huayao group, (2019), Annual Reports, Hangzhou, China: author.

[21] Huayao group, (2020), Annual Reports, Hangzhou, China: author. 